UDC 539.3; 624.073.4

\title{
STRESS - STRAIN STATE OF A THREE-LAYER CYLINDRICAL SHELL UNDER INTERNAL AXISYMMETRIC PULSE LOAD
}

\author{
V.V. Gaidaichuk, \\ Doctor in Engineering Science \\ K.E. Kotenko, \\ Ph.D. in Engineering Science \\ Kyiv National University of Construction and Architecture, \\ 31 Povitroflotskyi ave., Kyiv 03680
}

DOI: $10.32347 / 2410-2547.2020 .105 .145-151$

\begin{abstract}
The article presents the assessment results of the stress-strain state of a three-layer cylindrical shell with regard to its structural feature, the interrelation of the sheathing thicknesses and physical and mechanical characteristics of the solid polymer filler. Optimization of the structural concept is recommended.

Key words: three-layer cylindrical shell, polymer filler, axisymmetric pulse load, stress-strain state, finite element model.
\end{abstract}

\section{Introduction. Problem statement}

Over the last years, the amount of the layered shells used in different engineering and production areas has considerably increased. Characteristic aspects of the related design solutions were extended. The reliability control of that kind of structures became topical.

Based on the analysis performed, the solution methods for this issue is basically focused on ensuring such conditions at which the maximal stress-strain state values of the shell would not exceed the specified admissible values.

The restricted regulatory and methodological bases, as well as a relatively limited operating experience regarding the layered structures do not allow ensuring their reliability in full. Additional efforts facilitating the optimization of the structures' design and engineering solutions are required: determination of the rational balance of the structural elements' thicknesses, the appropriate selection of the related structural materials etc.

Efficiency effect of these efforts has been tested on the three-layer cylindrical shell under the conditions of rigid clamping of the shell ends. Three types of shells and the different polymer filler's physical and mechanical characteristics have been considered. Fig. 1 shows the shell's flowchart, which was analyzed. The shell's stress-strain state indexes have been investigated provided the following proportions of the shell's inner and outer sheathing thicknesses: $h_{1} / h_{3}=1, h_{1} / h_{3}=2, h_{3} / h_{1}=2$ (Table 1 ) and the ratios of physical and mechanical characteristics of the inner base layer and the integral filling material $E_{1} / E_{2}=$ 500 and $E_{1} / E_{2}=50$. Values of physical and mechanical characteristics were as follows: $E_{1}=E_{3}=70 \mathrm{MPa}, E_{2}=0.14$ and $1.4 \mathrm{MPa}, \mu_{1}=\mu_{3}=0.3, \rho_{1}=\rho_{3}=$ 


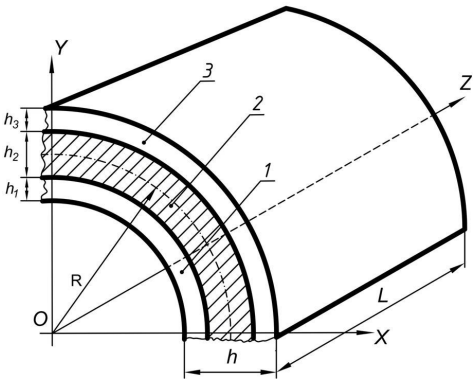

Fig. 1. Design of the three-layer shell: 1 - inner layer; 2 - filling material; 3 external layer
$2.7 * 10^{-3} \mathrm{~kg} / \mathrm{m}^{3}$. The shell's external diameter was $408 \mathrm{~mm}$ and its length $L$ was $250 \mathrm{~mm}$.

Table 1

Geometric parameters of the structural elements of the three-layer shell

\begin{tabular}{|l|c|c|c|c|c|}
\hline$h_{1}, \mathrm{~m}$ & $h_{3}, \mathrm{~m}$ & $h, \mathrm{~m}$ & $\frac{R}{h_{1}}$ & $\frac{L}{h_{1}}$ & $\frac{L}{R}$ \\
\hline $1 * 10^{-3}$ & $1 * 10^{-3}$ & $8 * 10^{-3}$ & 200 & 250 & 1.25 \\
\hline $2 * 10^{-3}$ & $1 * 10^{-3}$ & $9 * 10^{-3}$ & 100 & 125 & 1.25 \\
\hline $1 * 10^{-3}$ & $2 * 10^{-3}$ & $9^{*} 10^{-3}$ & 200 & 250 & 1.25 \\
\hline
\end{tabular}

The shell has been loaded by the axiosymmetrical internal impulse load (Fig. 2). Parameters of the internal load distribution $Q$ were set as follows:

$$
Q(t)=A^{*} \sin \frac{\pi^{*} t}{T},
$$

where: $A$ - amplitude of the impulsive power load; $T$ - load duration; $t$ - time interval.

The following loading parameters have been accepted: $A=10^{6} \mathrm{~Pa} ; T=$ $50 * 10^{-6} \mathrm{sec}$.

Provided the preset loading, calculations have been performed for the time interval $0 \leq t \leq 10 T$.

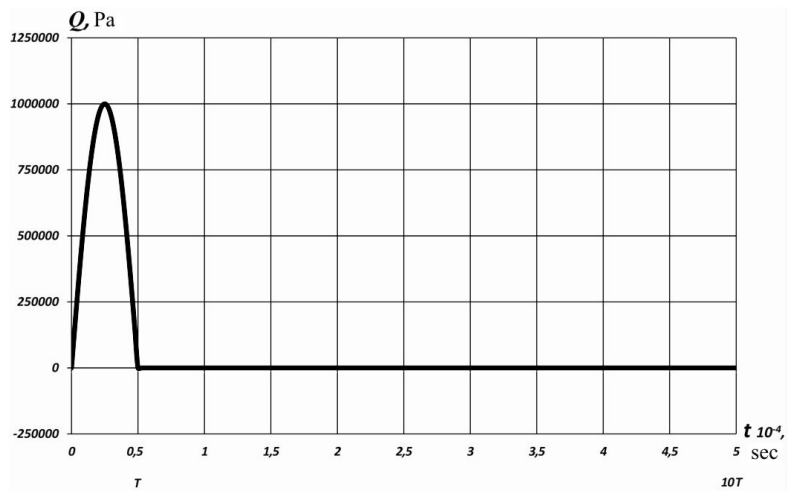

Fig. 2. Distribution of the internal load along the investigated time interval $(t)$

The stress-strain state indicators were calculated - the values of the displacements and stresses of the shell's bearing layers. Distribution of values of these indicators in the $X Z$ plane has been analyzed at the point of time when the displacement $T_{y}$ reached its maximal value within the time interval $t$. Calculations have been performed by the software package Nastran [6]. Values of displacements and stresses have been calculated by applying the direct transient dynamic process algorithm. The time interval was $0.0000025 \mathrm{sec}$, and 
the total number of steps was 200. Choice of the solid finite element type was conditioned by acquiring the more detailed and accurate calculation results. The finite element model (Fig. 3) included 19000 three-dimensional solid finite elements and 20800 nodes.

\section{Analysis of investigation results}

The dependence diagrams of values of the shell $T_{y}$ maximal displacements in Table $2(1-$ inner layer displacement, 2 - outer layer displacement) demonstrate that the shell with the

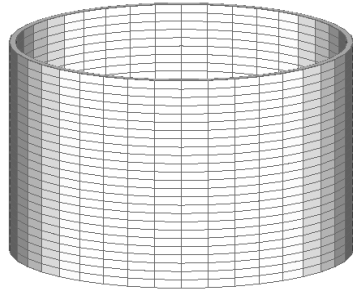

Fig. 3. The finite element model of the three-layer cylindrical shell equal inner and outer sheathing layers' thickness $\left(h_{1}=h_{3}\right)$ is the most deformation-yieldable.

Table 2

Maximal displacement $T_{y}$ of the shell sheathings having different layered structure and different physical and mechanical properties of the polymeric filler along the surveyed time interval $(t)$

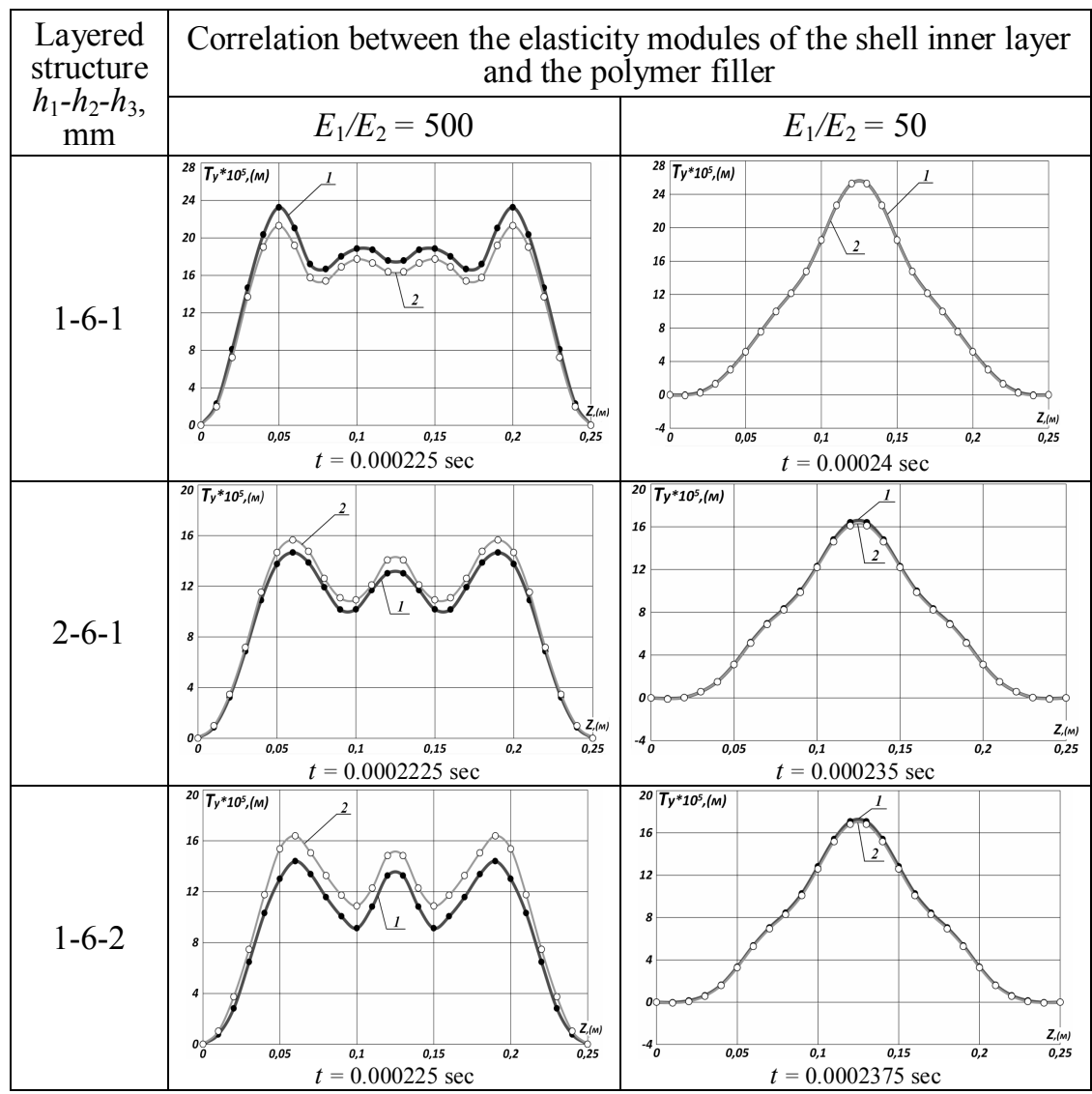


Its displacements $\left(T_{y}\right)$ have the maximal values of $0.000231587 \mathrm{~m}$ given $E_{1} / E_{2}=500$ at the moment of time $t=4.5 T(0.000225 \mathrm{sec})$ and $T_{y}=$ $0.00025297 \mathrm{~m}$ given $E_{1} / E_{2}=50$ at the moment of time $t=4.8 T(0.00024 \mathrm{sec})$. The increased thickness of just a single sheathing increases the aggregate deformational stability of the three-layer shell, whereas the effect can be quite considerable. Thus, in case the internal layer thickness is doubled, the maximal value of displacement $T_{y}$ decreases by almost 37\%. A similar pattern is observed in case of similar thickening of the outer sheathing. This behavior is observed at different ratios of physical and mechanical characteristics of the inner carrying layer and the solid polymer filler $E_{1} / E_{2}=500$ and $E_{1} / E_{2}=50$. And the value of the elasticity coefficient of the latter impacts considerably the displacement distribution $T_{y}$ along the shell length $L$. Thus, at $E_{1} / E_{2}=500$ (the polymeric filler elasticity coefficient $E_{2}=0.14 \mathrm{MPa}$ ) the distribution is quite

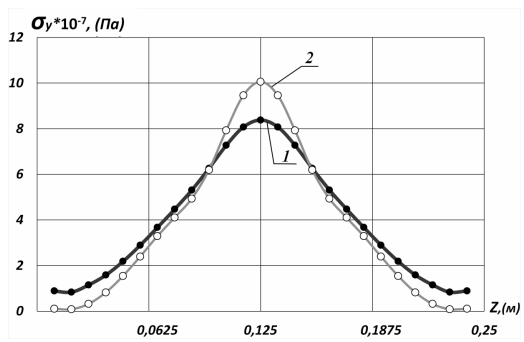

(a) $t=0.00024 \mathrm{~s}$

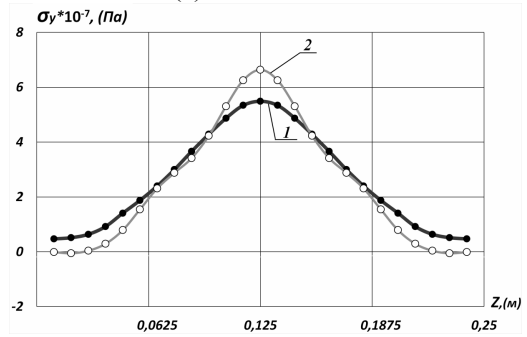

(b) $t=0.000235 \mathrm{~s}$

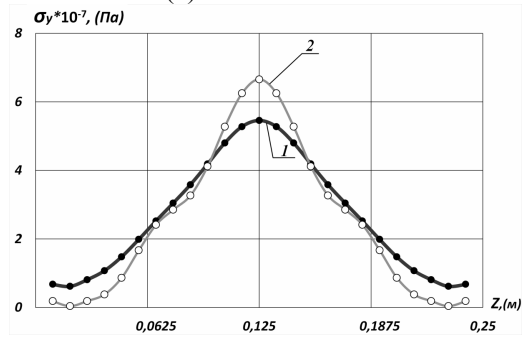

(c) $t=0.0002375 \mathrm{~s}$

Fig. 4. Maximal stress $\sigma_{y}$ of the sheathing bearing layers ( 1 - inner layer, 2 - outer layer) provided the ratio $E_{1} / E_{2 m}=50$ and the following layered structure of the sheathing $h_{1}-h_{2}-h_{3}, \mathrm{~mm}$ : (a) $1-6-1$; (b) $2-6-1$; (c) $1-6-2$ steady along the entire shell length with the peak values $0.000231587 \mathrm{~m}$ at $Z_{-}=0.05 \mathrm{~m} ; Z=0.2 \mathrm{~m}$. And at $E_{1} / E_{2}=50 \quad\left(E_{2}=1.4 \mathrm{MPa}\right)$, the displacement distribution $T_{y}$ decreases considerably and reaches its maximal value of $0.00025297 \mathrm{~m}$ in the shell center at $Z=0.125 \mathrm{~m}$ and falls dramatically close to its ends. At that, the displacement values of the inner and outer shell sheathings are almost equal.

Fig. 4 demonstrates the dependency graphs of the stress $\sigma_{y}$ maximal values related to the shell bearing layers (provided the correlation $\left.E_{I} / E_{2}=50\right)$ over the investigated time interval $(t)$.

As is obvious, the structure with the equal thickness of the shell's layers appeared to be the most strained. The alternate increase of the inner and outer sheathing thicknesses has lowered the maximal strain values by almost $34 \%$.

Comparison of the demonstrated results to the materials of other similar studies and cases [1-5, 7] evidence the integrity of the approach applied and the expediency of its application when defining the stress-strain state of the three-layer 
cylindrical sheathings within the time interval $0 \leq t \leq 10 T$, taking into account other predetermined statements.

\section{Conclusions}

Consideration was given to the dynamic deformation of the three-layer cylindrical sheathing under the conditions of the time-dependent loads in case of rigid clamping of the shell ends.

Impact of the geometric parameters of the shell's layers with different physical and mechanical properties of the integral filler on the stress-strain state under the axiosymmetrical internal impulse load conditions has been investigated.

Change in proportions between the thickness of the inner and outer sheathings of the shell considerably impacts the shell's stress-strain state and its performance. Increase of the inner sheathing thickness contributes significantly to the increase of the shell's performance.

Numerical results concerning the dynamics of the three-layer structure, which have been obtained by the finite-element method, allow providing the insight into the stress-strain state of the three-layer cylinder-type elastic structure at any point in time within the investigated temporary time interval.

\section{REFERENCES}

1. Lugovoi P.Z., Meish V.F., Meish Yu.A., Orlenko S.P. Dynamic Design of Compound Shell Structures of Revolution Under Nonstationary Loads //Intern. Appl. Mech. - 2020, 56, № 1 P. 22-32.

2. Andreev A.N., Nemirovskii Yu.V. Mnogosloynye anisotropnye obolochki i plastiny. Izgib, ustoychivost' i kolebaniya (Multilayered anisotropic shells and plates. Bending, stability and vibration). - Novosibirsk, Nauka Publ., 2002. - 288 p. (in Russian).

3. Bazhenov V.A., Krivenko O.P., Solovei N.A. Nelineinoe deformirovanie i ustoichivost' uprugikh obolochek neodnorodnoi struktury: Modeli, metody, algoritmy, maloizuchennye i novye zadachi (Nonlinear deformation and stability of elastic shells of non-uniform structure: Models, methods, algorithms, the insufficiently studied and new problems). Moskva, Knizhnyi dom «LIBROKOM», 2012. - 336 p.(in Russian).

4. Golovko, K.G., Lugovoi, P.Z., Meish, V.F. (2012). Dynamics of inhomogeneous shells under nonstationary loads. Ed. Guz A. N. - Kyiv: Publ. Center. "Kyiv University” (in Russian).

5. Pikul V.V. Mekhanika obolochek (Mechanics of shells). - Vladivostok, Dal'nauka, 2009. 536 p. (in Russian).

6. Rychkov S.P. MSC.visualNASTRAN dlia Windows (Modeling of structures in the environment MSC.visual NASTRAN for Windows). - Moscow: NT Press, 2004. - 552 p.

7. Solomonov Yu.S., Georgievskii V.P., Nedbai A.Ya., Prikladnye zadachi mekhaniki kompozitnykh cilindricheskikh obolochek (Applied problems of mechanics of composite cylindrical shells). - Moskva, Fizmatlit, 2014/ - 408 p. (in Russian).

Стаття надійшла 15.09.2020

Гайдайчук В.В., Котенко К.Е.

НАПРУЖЕНО-ДЕФОРМОВАНИЙ СТАН ТРИШАРОВОЇ ЦИЛІНДРИЧНОЇ ОБОЛОНКИ ПРИ ДІЇ ВНУТРІШНЬОГО ОСЕСІМ-МЕТРИЧНИОГО ІМПУЛЬСНОГО НАВАНТАЖЕННЯ

Розглянуто проблему динамічної деформації тришарової циліндричної оболонки при нестаціонарних навантаженнях у разі жорсткого затискання кінців оболонки. У статті представлені результати оцінки напружено-деформованого стану тришарової циліндричної оболонки з урахуванням іiї структурних особливостей, співвідношення товщини обшивки та 
фізико-механічних характеристик цілісного полімерного наповнювача. Розрахунки були проведені програмним комплексом Nastran. Значення переміщень i напружень розраховували за алгоритмом прямого перехідного динамічного процесу. Тривалість кроку інтервалу часу становила 0,0000025 с, а загальна кількість кроків - 200. Вибір типу тривимірного скінченного елемента був обумовлений отриманням більш детальних і точних результатів розрахунку. Модель скінченних елементів включала 19000 тривимірних скінченних елементів і налічувала 20800 вузлів. Досліджено вплив геометричних параметрів шарів оболонки 3 різними фізико-механічними властивостями цілісного наповнювача на напружено-деформований стан при осесиметричному внутрішньому імпульсному навантаженні. Чисельні результати щодо динаміки тришарової структури, отримані методом скінченних елементів, дозволяють охарактеризувати напруженодеформований стан тришарової пружної структури циліндричного типу в будь-який час досліджуваного інтервалу часу. Рекомендується оптимізація конструкції оболонки. Зміна співвідношення товщини внутрішньої та зовнішньої шарів оболонки суттєво впливає на напружено-деформований стан оболонки та ії експлуатаційні характеристики. Збільшення товщини внутрішнього шару оболонки суттєво сприяє збільшенню останньої. Порівняння наведених результатів 3 матеріалами інших подібних досліджень та позицій, свідчать про об'єктивність зробленого підходу.

Ключові слова: тришарова циліндрична оболонка, полімерний наповнювач, імпульсне осесиметричне навантаження, напружено-деформований стан, скінчено-елементна модель.

\section{Gaidaichuk V. V., Kotenko K. E.}

\section{STRESS - STRAIN STATE OF THE THREE-LAYER CYLINDRICAL SHELL UNDER} INTERNAL AXISYMMETRIC PULSE LOAD

The problem of dynamic deformation of a three-layer cylindrical shell under non-stationary loads in the case of rigid clamping of the shell ends is considered. The article presents the results of assessing the stress-strain state of a three-layer cylindrical shell, taking into account its structural feature, the ratio of the sheathing thickness and the physical and mechanical characteristics of a one-piece polymer filler. Calculations were performed by software complex Nastran. The values of displacements and stresses were calculated by the algorithm of direct transient dynamic process. The step duration of the time interval was $0.0000025 \mathrm{~s}$, and the total number of steps was 200. The choice of the type of three-dimensional finite element was due to obtaining more detailed and accurate calculation results. The finite element model included 19000 three-dimensional finite elements and numbered 20800 nodes.

The influence of geometrical parameters of shell layers with different physical and mechanical properties of one-piece filler on the stress-strain state under axisymmetric internal impulse load is investigated. Numerical results on the dynamics of the three-layer structure, obtained by the finite element method, allow to characterize the stress-strain state of the three-layer elastic structure of the cylindrical type at any time in the studied time interval. Optimization of the shell design is recommended. Changing the ratio of the thickness of the internal and external shells of the shell significantly affects the stress-strain state of the shell and its performance. Increasing the thickness of the internal layer of the shell significantly contributes to the increase of the latter. Comparison of the given results with materials of other similar researches and positions, testify to objectivity of the made approach.

Key words: three-layer cylindrical shell, polymer filler, pulse axisymmetric load, stress-strain state, finite element model.

\section{Гайдайчук В.В., Котенко К.Э.}

\section{НАПРЯЖЕННО-ДЕФОРМИРОВАННОЕ СОСТОЯНИЕ ТРЕХСЛОЙНОЙ ЦИЛИНДРИЧЕСКОЙ ОБОЛОЧКИ ПРИ ДЕЙСТВИИ ВНУТРЕННЕЙ ОСЕСИММЕТРИЧНОЙ ИМПУЛЬСНОЙ НАГРУЗКИ}

В статье приведены результаты оценки напряженно-деформированного состояния трехслойной цилиндрической оболочки, учитывающие ее структурную особенность, соотношение толщины обшивки и физико-механические характеристики цельного полимерного наполнителя. Рекомендуется оптимизация конструкционного решения оболочки.

Ключевые слова: трехслойная цилиндрическая оболочка, полимерный наполнитель, импульсная осесимметричная нагрузка, напряженно-деформированное состояние, конечноэлементная модель 


\section{УДК 539.3}

Гайдайчук B.B., Котенко К.E. Напружено-деформований стан тришарової циліндрічної оболонки при внутрішньому осесиметричному імпульсному навантажені // Опір матеріалів і теорія споруд: наук.-тех. збірн. - К.: КНУБА, 2020. - Вип. 105. - С. 145-151.

У статті наведено результати оцінки напружено-деформованого стану тришарової циліндричної оболонки, враховуючі їі структурну особливість, співвідношення товщини обшивки $i$ фізико-механічні характеристики цільного полімерного наповнювача. Рекомендується оптимізаиія конструкиійного рішення оболонки.

Табл. 2. Іл. 4. Бібліогр. 7 назв.

\section{UDC 539.3}

Gaidaichuk V.V., Kotenko K.E. Stress-strain state of a three-layer cylindrical shell under internal axisymmetric pulse load // Strength of Materials and Theory of Structures: Scientificand-technical collected articles - Kyiv: KNUBA, 2020. - Issue 105. - P. 145-151.

The article presents the results of assessing the stress-strain state of a three-layer cylindrical shell, taking into account its structural feature, the ratio of the sheathing thickness and the physical and mechanical characteristics of a one-piece polymer filler. Optimization of the shell design is recommended.

Tabl. 2. Fig. 4. Ref. 7.

\section{УДК 539.3}

Гайдайчук $B . B$. ., Котенко К.Э. Напряженно-деформированное состояние трехслойной цилиндрической оболочки при действии внутренней осесимметричной импульсной нагрузки // Сопротивление материалов и теория сооружений. - 2020. - Вып. 105. - С. 145151.

В статье приведены результаты оценки напряженно-деформированного состояния трехслойной цилиндрической оболочки, учитывающие ее структурную особенность, соотношение толщины обшивки и физико-механические характеристики цельного полимерного наполнителя. Рекомендуется оптимизация конструкиионного решения оболочки.

Табл. 2. Ил. 4. Библиогр. 7 назв.

Автор (вчена ступень, вчене звання, посада): доктор технічних наук, професор, завідувач кафедри теоретичної механіки Київського національного університету будівництва і архітектури ГАЙДАЙЧУК Віктор Васильович.

Адреса робоча: 03680 Украӥна, т. Київ, проспект Повітрофлотський, 31, к. 433, Київський національний університет будівництва $і$ архітектури, кафедра теоретичної механіки, ГАЙДАЙЧУКУ Віктору Васильовичу.

Роб. тел. +380 (44) 241-55-72

Моб. тел. +380 (97) 542-94-27

E-mail: viktor_gaydaychuk@bigmir.net

ORCID ID: http://orcid.org/0000-0003-2059-7433

Автор (вчена ступень, вчене звання, посада): кандидат технічних наук, доцент кафедри теоретичної механіки Київського національного університету будівництва і архітектури КОТЕНКО Костянтин Едуардович.

Адреса робоча: 03680 Украӥна, т. Київ, проспект Повітрофлотський, 31, к. 433, Київський начіональний університет будівництва і архітектури, кафедра теоретичної механіки, КОТЕНКУ Костянтину Едуардовичу.

Роб. тел. +380 (44) $241-55-72$

Моб. тел. +380 (94) 855-09-37

E-mail: 1969box@mail.ru

ORCID ID: https://orcid.org/0000-0002-3181-3819 